doi: $10.31140 / j . v e s t n i k i b .2017 .2(200) \cdot 9$

\title{
ЮРИЙ ПАВЛОВИЧ ЮДИН. 110 ЛЕТ СО ДНЯ РОЖДЕНИЯ
}

\author{
Л.Я. Огродовая \\ Федеральное государственное бюджетное учреждение науки \\ Институт биологии Коми научного центра Уральского отделения РАН, Сыктывкар
}

Юрий Павлович Юдин прожил недолгую, но плодотворную жизнь, в течение которой он беззаветно отдавал все свои силы научной работе в мирные дни и защите нашей Родины на фронтах Великой Отечественной войны.

После выбора Юрием Павловичем своего жизненного пути в его судьбе четко прослеживаются три периода. Довоенный (1929-1941 гг.), во время которого происходило его вхождение в науку в процессе учебы в университете и становление его как выдающегося ученого-геоботаника во время работы в крупных экспедициях в разных районах Советского Союза - от Хибин до Западной Сибири, от Большеземельской тундры до Северного Кавказа и Средней Азии.

Однако, успешно и плодотворно начавшаяся научная деятельность Ю.П. Юдина была прервана войной. С 1942 по 1945 г. Юрий Павлович был на фронте, выполняя общую тогда для всего нашего народа тяжелую работу по освобождению страны от страшного врага.

После окончания войны Юрий Павлович вернулся к научной работе и уже не расставался с Севером, полностью посвятив себя изучению растительности Коми края. По объему проделанной в этот период (1946-1952 гг.) работы, широте охвата и глубине проведенных исследований, это было время масштабных трудов и гениальных прозрений уже зрелого Мастера.

Родился Юрий Павлович Юдин 21 декабря 1907 г. в г. Полоцке Витебской губернии в семье фельдшера. Окончив среднюю школу в г. Любань Ленинградской области, куда из Белоруссии переехали его родители, он поступил в Ленинградский промышленно-экономический техникум, после окончания которого некоторое время работал на Октябрьской железной дороге.

В 1929 г. Юрий Павлович поступает на биологический факультет Ленинградского государственного университета и в 1933 г. оканчива-

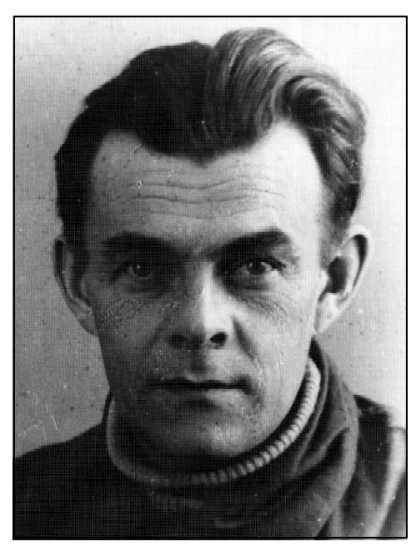

Юрий Павлович Юдин 21.12.1907-02.09.1952 зу он стал начальником Печорской геоботанической экспедиции, которая работала под общим руководством члена-корреспондента АН СССР Александра Петровича Шенникова.

В 1934-1935 гг. сотрудниками Печорской экспедиции были проведены первые геоботанические исследования в Вымско-Вычегодском бассейне и на левобережье верхней Печоры. Помимо участия в составлении свода отчетов и Геоботанического очерка, вышедшего под редакцией А.П. Шенникова, по итогам этой экспедиции Ю.П. Юдин самостоятельно подготовил научные рает его практически готовым специалистом-геоботаником, поскольку будучи еще студентом, он вклютается в полевые әкспедиционные работы.

Так, в 1931 г. он впервые в качестве геоботаника принимал участие в Кольской геоботанической экспедиции АН CCCP, которая под руководством профессора Н.А. Аврорина проводила исследования в районе Хибинских гор. А в 1932 г. уже в составе Западно-Сибирской экспедиции, работавшей нод руководством академика В.Н. Сукачева, Ю.П. Юдин самостоятельно обследовал растительность бассейна р. Конды. Полученные материалы были им систематизированы и легли в основу его дипломной работы, а также - отдельной статьи, посвященной липе.

1933 г. был отдан изучению оленьих пастбищ на Полярном Урале. А после окончания университета Юрий Павлович был принят на работу в Ботанический институт АН СССР на должность младшего научного сотрудника. Практически сра- боты «Растительность Вымско-Вычегодской части области Коми» и «Растительность восточной части Ижма-Печорского междуречья».

В 1936-1937 гг. Юрий Павлович работал в Северной Базе АН СССР в Архангельске и принял участие в экспедиции под руководством известного исследователя Севера - Александра Иннокентьевича Толмачева. Это позволило ему провести изучение луговой, в том числе и сорной, рас'тительнос'ти на территории нынешней Вологодской области и в районе дельты Северной Двины. Результаты работ были систематизированы Ю.П. Юдиным и отражены в его научной работе «Сорная флора Северного края» и в монографии «Сорно-полевые растения северных областей (Apхангельская обл., средняя и восточная части Вологодской обл.)".

В 1938 г. Ю.П. Юдин провел геоботанические исследования на Северном Кавказе в составе Лабинской экспедиции Ботанического института АН 
CCCP, в 1939 г. - в районе нижнего течения p. Кафиринган в Таджикистане. Одновременно с 1934 по 1939 г. ученый по заданию Ботанического института АН СССР участвовал в составлении геоботанической карты европейской части СССР.

В 1940-1941 гг. судьба снова привела Ю.П. Юдина на Север - в составе Большеземельской экспедиции Наркомзема РСФСР он провел геоботанические исследования тундр и таежных территорий на Тимане, в Ухтинском, Ижемском и Усть-Цилемском районах Коми АССР.

По материалам, собранным во время экспедиций, Юрием Павловичем была подготовлена кандидатская диссертация, защитить которую помешала война. В феврале 1942 г. он был мобилизован на фронт, воевал в составе Карельского и Украинского фронтов, дважды был ранен и прошел с боями Румынию, Венгрию, Австрию и Чехословакию. Воинская доблесть ученого отмечена наградами - «За отвагу», «За боевые заслуги», «За взятие Вены».

Только в ноябре 1945 г. Юрий Павлович вернулся домой и снова приступил к прерванной войной деятельности. Уже с 1 января 1946 г. он был принят на работу в недавно созданную Научно-исследовательскую Базу АН СССР в Коми ACCP в Сыктывкаре.

Выбор им места работы не был случайным до войны по территории Коми Юрием Павловичем была пройдена не одна сотня километров, собран богатый материал о растительном покрове, анализу которого уже был посвящен целый ряд его научных статей. Итоги исследований Ю.П. Юдина были высоко оценены Александром Петровичем Шенниковым, который подчеркивал, что этот ученый зарекомендовал себя как геоботаник с широким научным кругозором, особенно много и плодотворно работающий над изучением растительного мира Севера.

Однако, несмотря на свою известность, на работу в сектор геоботаники Юрий Павлович был принят только на должность младшего научного сотрудника, так как к тому времени еще не имел ученой степени. Не помогло и ходатайство руководителей Коми базы Академии наук в Президиум АН СССР о принятии Юдина на должность старшего научного сотрудника в порядке исключения как уже известного геоботаника.

К тому времени Ю.П. Юдину не исполнилось еще и 40 лет, но он как будто чувствовал, что жить ему осталось совсем недолго, поэтому со всей присущей ему энергией включился в работу, не пропуская ни одного экспедиционного периода. Он исследовал ряд труднодоступных и ранее в литературе почти не охарактеризованных в геоботаническом отношении районов Коми - бассейны рек Щугора и Подтерема, Цильмы, Северной Кельтмы, был бессменным начальником геоботанических полевых отрядов.
Ю.П. Юдин вкладывал в работу много знаний и личной энергии и всегда добивался полного выполнения намеченной программы исследований, несмотря на значительные в послевоенное время трудности в обеспечении полевых работ. Он со спокойным мужеством и находчивостью принимал решения в самых сложных обстоятельствах. Трудился в экспедициях не жалея себя, но стараясь обеспечить своих сотрудников временными помощниками, на оплату которых денег всегда не хватало.

Отчеты экспедиций Ю.П. Юдина отличаются обстоятельностью изложения, насыщены конкретными данными и являются источником ценной информации, не потерявшей своего значения до сих пор.

Только за 1946-1948 гг. обследованная ученым площадь составила 17 тыс. км² но около 3 тыс. км рабочих маршрутов, сделано 540 геоботанических описаний, собрано 2100 гербарных экземпляров растений, составлено семь листов геоботанической карты М 1:500 000 .

Работая в течение ряда лет в геоботанических экспедициях на Северном и Полярном Урале, в Большеземельской тундре, в бассейнах рек Печоры и Вычегды, Ю.П. Юдин прекрасно изучил растительность республики. Обладание глубокими геоботаническими знаниями и понимание взаимосвязей различных компонентов экосистем позволило ему сформировать схему геоботанического районирования территории Коми (включающую три подпровинции и 41 округ), предложить уточненные границы подзон растительности, составить комплексную характеристику вертикальной поясности и высотных пределов лесной растительности в горах Урала. Эти материалы до сих пор широко используют специалисты различных профилей.

Логическим продолжением способности Юрия Павловича - наблюдая и изучая частное перейти к пониманию целого - стала его активная работа над составлением геоботанической карты Коми $\operatorname{ACCP~(M~1:1~} 000$ 000) и карты растительности Коми ACCP (М 1:1 000 000). Он был идейным вдохновителем создания монографии «Флора Коми АCCP», над которой работал в составе коллектива авторов; подготовил материал для издания «Определитель типов лесов Коми АССР», часть которого - «Определитель типов лесов южной части Коми ACCP»- была написан им лично.

Параллельно Юрий Павлович работал над своей кандидатской диссертацией по теме «Темнохвойные леса Коми АССР (геоботаническое описание)", которую он блестяще защитил 18 октября 1950 г., и за которую ему была присуждена ученая степень кандидата биологических наук. Ровно терез месяц после защиты, 18 декабря 1950 г. решением Бюро совета филиалов АН СССР Ю.П. Юдин был переведен на должность старшего научного сотрудника. 
Типизации темнохвойных лесов Ю.П. Юдин уделял особое внимание. В своей диссертации он впервые привел описание и дал детальную классификацию еловых, пихтовых и кедровых лесов для всей территории Коми АССР, выявил основные закономерности их развития. Практическое значение этой работы, помимо инвентаризации и классификации хвойных лесов, заключается в том, что она описывает процесс сменяемости типов лесов в зависимости от экотопических условий и может служить основой для выработки лесохозяйственных мероприятий, направленных на возобновление лесов на гарях и вырубках, на предотвращение заболачивания.

Данные Ю.П. Юдиным описание и глубокий анализ растительности, в том числе типология темнохвойных и лиственничных лесов, горных березовых лесов и горных тундр, отражены в монографии «Производительные силы Коми АССР», над геоботаническими разделами которой он работал.

Несмотря на трудности послевоенных лет, Юрий Павлович умел создать вокруг себя творческую атмосферу. Он охотно делился с товарищами идеями, планами работ; принимал живое участие в обсуждении самых разных вопросов, особенно касающихся образования видов, палеоботаники, четвертичного оледенения, в ходе которых проходили проверку и его интуитивные прозрения.

Особый научный интерес для Ю.П. Юдина представляли произрастающие на известняках реликтовые флористические комплексы, изучению которых он посвятил несколько лет своей короткой жизни. В самом начале научной деятельности Юрий Павлович обратил внимание на растения, не свойственные лесной зоне Севера, места произрастаний которых приурочены к выходу на дневную поверхность известьсодержащих горных пород. Обладая широким кругозором и пониманием целостности мира природы и взаимосвязанности процессов, Юрий Павлович предпринял попытку реконструкции истории флоры и растительности европейского Северо-Востока и дал свое объяснение причинам образования таких реликтовых комплексов.

Современники ученого отмечали, что он весь был поглощен работой, легко писал, быстро оформлял полученные научные данные, внимательно следил за появлением новых публикаций, часто являлся рецензентом крупных монографических работ. Сам помимо научных статей писал стихи и пробовал свои силы в прозе, был интересным, эрудированным и остроумным собеседником.

Жизнь Юрия Павловича оборвалась в самом расцвете его творческих сил. Сказались последствия тяжести фронтовой жизни, да и первых послевоенных лет - несмотря на лечение, организм ученого не смог справиться с туберкулезом.

Ю.П. Юдин ушел из жизни 2 сентября 1952 г., так и не успев защитить докторскую диссертацию, посвященную реликтовым флористическим комплексам на Севере («Реликтовая флора известняков северо-востока европейской части СССР»), над которой работал до последних дней и по теме которой им уже были написаны основные разделы монографии.

После ухода Юрия Павловича рукопись его монографии была доработана и подготовлена к печати коллегой и верным последователем ученого, впоследствии известным геоботаником Ариадной Николаевной Лащенковой, и в 1954 г. напечатана в IV выпуске сборника «Материалы по истории флоры и растительности СССР», издаваемого АН СССР.

За недолгую творческую жизнь Юрием Павловичем написано 67 научных трудов, из которых больше половины - за время его работы в Коми филиале АН СССР. Рукописное наследие Ю.П. Юдина хранится в фондах Ботанического института РАН и Коми научного центра УрО РАН, 24 работы ученого опубликованы в центральных изданиях - в «Ботаническом журнале» и "Трудах Ботанического института АН СССР».

Материалы исследований Ю.П. Юдина не устаревают, они остаются источником ценнейших геоботанических описаний и картографических документов и активно используются современными исследователями, продолжающими изучение природных комплексов Республики Коми. Объем и значение проделанной Юрием Павловичем Юдиным научной работы и масштаб его личности вдохновляют всё новые поколения ученых на самоотверженное служение Науке.

Составлено по материалам издания: Забоева, И. В. Юрий Павлович Юдин (страницы биографии геоботаника - одного из основоположников исследований растительности Республики Коми) / И. В. Забоева ; отв. ред. Н. С. Котелина. - Сыктывкар : Коми НЦ УрО РАН, 1997. - 24 с. - (Серия «Люди науки» ; вып. 26).

\section{YURIY PAVLOVICH YUDIN. 110 YEARS FROM THE BIRTHDAY}

\section{L.Y. Ogrodovaya}

Institute of Biology of Komi Scientific Centre of the Ural Branch of the Russian Academy of Sciences, Syktyvkar

Summary: Yuriy Pavlovich Yudin - great scientist and botanist, who devoted his whole life to studying the vegetation of the Komi ASSR.

Being the student of the Leningrad University he actively participated in scientific expeditions to the Russian European North and proved himself as outstanding researcher of the nature. In 1933, upon completion of the 
University, Y.P. Yudin began his scientific research in the Komi Republic, worked in geobotanical expeditions in Northern and Polar Urals, Bolshezemelskaya tundra, the Pechora and Vychegda basins.

Before the II World War he provided phytocoenological studies in the Tadjik SSR, in the North Caucasus, Kola Peninsula and West Siberia. He also participated in the creation of a vegetation map of the European part of the USSR.

Y.P. Yudin participated in the creation of a geobotanical map and vegetation map of the Komi ASSR, developed the scheme of geobotanical zoning of Komi and defined the borders of vegetation subzones. He was the ideological inspirer of the creation of the monograph «Flora of the Komi ASSR», prepared material for the publication «Determinant of forest types of the Komi Republic». He personally wrote the phytocoenological sections in the monograph "Productive forces of the Komi Republic".

Y.P. Yudin defended his candidate thesis named "Dark coniferous forests of the Komi ASSR (geobotanical description)", in which he paid particular attention to the forest typology.

He especially interested in limestone relic plant complexes that he studied for some years of his short life. The monograph «Relic flora of limestones in the USSR European Northeast» devoted to these complexes was published after his dead.

Y.P. Yudin had extraordinary working capacity, unflagging interest in his work and selfless service to Russian science. He participated in the II World War where was wounded twice and was rewarded with battle awards.

Перевод на английский: Ю. Дубровский

\section{ИНФОРМАЦИЯ В НОМЕР}

\section{III Всероссийская научная конференция «БИОРАЗНООБРАЗИЕ ЭКОСИСТЕМ КРАЙНЕГО СЕВЕРА: ИНВЕНТАРИЗАЦИЯ, МОНИТОРИНГ, ОХРАНА"}

Уважаемые коллеги!

Институт биологии Коми НЦ УрО РАН приглашает вас принять участие в работе III Всероссийской научной конференции «Биоразнообразие экосистем Крайнего Севера: инвентаризация, мониторинг, охрана», которая состоится 20-24 ноября 2017 г. в г. Сыктывкар (Республика Коми, Россия).

Крайний Север - обширный регион с ярко выраженными географическими, климатическими, социокультурными особенностями и уникальным природно-ресурсным потенциалом. Он охватывает материковую часть суши, протянувшуюся от полярных пустынь до лесотундры как экотона между тундрой и тайгой, расположенную севернее Полярного круга; акватории пяти морей и большей части бассейна Северного Ледовитого океана. В горных условиях высотные аналоги арктических әкосистем (биогеоценозов) расположены выше границы леса. В настоящее время данный район, где имеются все характерные типы экосистем, включающие большинство видов мировой арктической биоты, рассматриваются как самостоятельный объект государственной политики, обусловленной национальными интересами России. Крайний Север - это и мощный источник природных ресурсов. Их интенсивное освоение в последние десятилетия оказывает все большее негативное влияние на природные ландшафты, что обуславливает необходимость интенсификации всестороннего изучения северных экосистем, уязвимых техногенному воздействию; предполагает активизацию разработки стратегии сохранения эталонных ландшафтов и редких видов; определяет потребность в оценке устойчивости природных комплексов и потенциала их естественного восстановления. Учитывая большой интерес широкого круга исследователей к проблемам изучения экосистем Крайнего Севера, проявленный на предыдущей конференции с одноименным названием, принято решение следующее совещание по данной тематике провести в ноябре 2017 г. в г. Сыктывкаре.

Инициаторами научного мероприятия выступают Институт биологии Коми НЦ УрО РАН, Коми отделение РБО, Министерство промышленности, природных ресурсов, энергетики и транспорта Республики Коми, Управление Росприроднадзора по Республике Коми.

На конференцию приглашаются ученые и специалисты научных центров, институтов, выспाих учебных заведений, сотрудники особо охраняемых природных территорий Крайнего Севеpa, представители органов государственной власти, руководители заинтересованных организаций и предприятий. 